\title{
Punishing Violent Thoughts: Islamic Dissent and Thoreauvian Disobedience in Post-9/ I I America
}

\author{
REBECCA RUTH GOULD
}

American Muslims increasingly negotiate their relation to a government that is suspicious of Islam, yet which recognizes them as rights-bearing citizens, within a culture they claim as their own. To better understand how the post-9/I I state is reshaping American Islam, I examine the case of Muslim American dissident Tarek Mehanna, sentenced to seventeen years in prison in 2012 for providing material support for terrorism. I read Mehanna's verbal and visual depictions of his persecution in relation to the American dissidents Mehanna claims as intellectual predecessors, above all Henry David Thoreau and John Brown, while situating this dissent within a long history of American activism

Under a government which imprisons anyone unjustly, the true place for a just man is also a prison.

Henry David Thoreau, "Resistance to Civil Government"

Well over three million Muslims live in the United States. ${ }^{I}$ Islam is the thirdlargest US religion, following Christianity and Judaism. ${ }^{2}$ American Islam is more than a demographic phenomenon; scholarship is gradually revealing a rich literary Muslim American tradition, in many languages, and comprising many cultures, including slave narratives in Arabic that date back to the earliest days of the American republic. ${ }^{3}$ Yet for many within, as well as outside, the United States, the phrase "American Islam" still sounds like a contradiction

College of Arts \& Law, University of Birmingham. Email: r.r.gould@bham.ac.uk.

${ }^{1}$ Besheer Mohamad, “A new estimate of the U.S. Muslim population,” Pew Research, 6 Jan. 2016, at www.pewresearch.org/fact-tank/2016/01/06/a-new-estimate-of-the-u-s-muslimpopulation.

2 John Esposito, "Muslims in America or American Muslims?", in Yvonne Yazbeck Haddad and John L. Esposito, eds., Muslims on the Americanization Path? (Oxford: Oxford University Press, 2000), 3-19, 3.

3 See, for example, Muhammad al-Ahari, ed., Five Classic Muslim Slave Narratives: Selim Aga, Job Ben Sulaiman, Nicholas Said, Omar ibn Said, Abu Bakr Sadiq (Chicago: Magribine Press, 2006). 


\section{Rebecca Ruth Gould}

in terms. President Trump's Muslim ban is only the latest in a long series of attempts to represent Islam as inherently alien to American culture. The religious, ethnic, and even linguistic implications of American Islam defy ingrained stereotypes. Americans who complicate the monochromatic image of America frequently evoke surprise while traveling abroad when they diverge from these stereotypes. ${ }^{4}$ The false perception of a monochrome America retains its hold on the popular imagination, within the United States and globally.

Yet America has been multi-confessional and multiethnic since its beginnings. While America's diversity results in part from historical factors, including its precolonial indigenous populations and slavery, this diversity has more recently been affected by a substantial number of migrants from South Asia, Afghanistan, and the Arab world, many of whom, although not all, are Muslim. First-generation Muslim Americans increasingly link the non-American aspects of their history, be it Pakistani, Egyptian, Iraqi, or Afghan, to their American selves. These hybrid identities are redefining the content of American Islam, and this redefinition calls for rigorous scrutiny and critical theorization.

This essay tracks the transnational trajectory of one such hybrid identity, formed in the context of a post-9/i I US-led war on terror: the Americanborn Muslim Tarek Mehanna (b. 1980), from Sudbury, Massachusetts, of Egyptian descent. Mehanna was convicted of providing "material support" to foreign terrorists in 2012 and is currently serving a seventeen-year prison sentence. 5 Political theorists and legal scholars have written eloquently and persuasively about the dangerous legal precedent set by Mehanna's case. They have focussed on how this precedent empowers the US government to criminalize protected speech, and to prosecute thought as dangerous in itself, apart from its actual consequences. ${ }^{6}$

While informed by such legal analyses, this essay takes a different turn. Through an analysis of his sentencing statement, delivered in 2012 , and the visual sketches that preceded it, I explore the intellectual origins of Mehanna's mode of dissent, and analyze his location within the American tradition of civil disobedience. ${ }^{7}$ I focus on how Mehanna's appropriation of

4 The experience of African Americans abroad has been extensively documented in this regard. See Gary Totten, African American Travel Narratives from Abroad: Mobility and Cultural Work in the Age of Jim Crow (Amherst: University of Massachusetts Press, 20 1 5).

5 The Supreme Court ruling around which the prosecution built their case against Mehanna is Holder v. Humanitarian Law Project (2010), at www.supremecourt.gov/opinions/ogpdf/ 08-I 498.pdf.

${ }^{6}$ See Andrew March, "A Dangerous Mind?", New York Times, 2 I April 2012, SR I; Amna Akbar, "How Tarek Mehanna Went to Prison for a Thought Crime," The Nation, 3 I Dec. 2016, at www.thenation.com/article/how-tarek-mehanna-went-prison-thought-crime.

7 A more recent source for Mehanna's thinking which was not formally taken into consideration while working on this article are the posts on a Facebook page curated by his 
Thoreau fits into a longer history of American dissidence. While recognizing that Mehanna's failure thus far to critically interrogate the violent premises of some of his Islamist texts is a significant weakness in his thinking to date, my interest lies more in his adaptation of core elements in American intellectual history to a Salafist Muslim identity. ${ }^{8}$ Alongside its status as a litmus test of the limits of the American justice system, Mehanna's case marks a new, yet familiar, moment in the history of American civil disobedience.

In bringing this complex legal precedent to bear on the study of Muslim American intellectual history, I want to suggest how, due to its progressive transnationalization and its changing internal demographics, American studies has entered a new phase. Mehanna's case matters, and not just for what it tells us about the changing ethos of the US justice system and its increasing reliance on "innuendo and association" in a post-9/I I age.9 Equally, it is important for what it teaches us about America's changing intellectual landscape. While Mehanna's Muslim identity made him a target for prosecution, his familiarity with the classics of American literature and iconic moments in American history conditioned his ethics of dissent. Mehanna's program for political action, including its problematic association with violence, belongs to an evolving indigenous tradition of American Islam, of which Mehanna's is but one of many versions. While Mehanna, who affiliates with Salafism, a form of Islam that originated in Saudi Arabia which is linked to the conservative Hanbali school of Islamic jurisprudence, does not speak for all or even most Muslims, his thinking overall offers insight into the dialectics of American and Muslim identity today. In order to understand as well as resist the appeal of violence domestically and globally, we must come to terms with its original context, including its American history.

\section{THE CASE AGAINST MEHANNA}

On I2 April 20 I2, Tarek Mehanna received a seventeen-year prison sentence for providing "material support” for al Qaeda. As legal scholar Amna Akbar

brother, and regularly updated with reports from prison: www.facebook.com/Free

TarekMehanna. This page has over 6,000 followers as of this writing.

8 The main Islamist text that Mehanna translated and disseminated on the Internet and which was a focus of his conviction is Muhammad bin Ahmad as-Salim (Isa al-Awshin), "39 Ways to Serve and Participate in Jihad, at-Tibyan" (pdf at Internet Archive, ia600405.us.archive.org). Although the prosecution could not demonstrate any use of this work by al Qaeda, Mehanna's promotion of this text was nonetheless regarded as "material support" for this terrorist group. See Wadie E. Said, Crimes of Terror: The Legal and Political Implications of Federal Terrorism Prosecutions (Oxford: Oxford University Press, $2015), 70$.

9 This phrase is taken from Akbar. 


\section{Rebecca Ruth Gould}

notes, the government provided no evidence that Mehanna "acted at the group's request, or even that he ever met or communicated with anyone from Al Qaeda." " I It was not necessary for the government to prove collusion with any terrorist organizations in order to secure a conviction. It was enough to demonstrate that Mehanna "created and/or translated, accepted credit for authoring, and distributed text, videos, and other media, to inspire others to engage in violent jihad." ${ }_{11}$

The ruling against Mehanna, and his extreme punishment, have been criticized by scholars of the First Amendment as "not properly founded in First Amendment law or statutory interpretation." ${ }^{22}$ Critics note that in Mehanna's case "material support" amounted to nothing more than posting on an online forum, maintaining a blog, and translating into English Arabic material supportive of jihad. ${ }^{13}$ There were related charges, including a trip to Yemen that the prosecution claimed was motivated by the intention to join a terrorist training camp, but these charges were never proven and did not constitute the basis of the case against Mehanna. As matters currently stand, Mehanna will pass the years 20 I 2-29 in solitary confinement in a supermax prison, as a result of his controversial beliefs.

Mehanna's conviction typifies the legal culture of post-9/ I I America. Already in 2007, it was possible to point to "twelve hundred Muslim and Arab men" who were detained by US authorities in late $200 \mathrm{I}$ and to the "subsequent interrogation of eight thousand more." ${ }^{14}$ Yet with regard to the crime with which he was charged, Mehanna's conviction marks a new stage in the US war on terror. It indicates that the government need not provide evidence of the intention to perpetrate a terrorist act in order to secure a felony conviction. According to one legal scholar, Mehanna's conviction "may have succeeded in pushing the doctrinal envelope," effectively changing the meaning of "material support" within US law. ${ }^{\text {Is }}$ Another specialist in the First Amendment notes that the case of Mehanna, like that of Julian Assange, illustrates "the complexities associated with the exercise of First Amendment liberties in an emerging global theatre." I6

10 Ibid.

${ }^{11}$ Quoted from United States of America v. Tarek Mehanna and Ahmad Abusamra, archived at www.investigativeproject.org/documents/case_docs/r726.pdf.

${ }_{12}$ Nikolas Abel, "Note - U.S. v. Mehanna, the First Amendment, and Material Support in the War on Terror," Boston College Law Review, 54 (2013), 7 I I-50, 7 I 2.

${ }_{13}$ On the "material support" accusation see George D. Brown, "Notes on a Terrorism Trial: Preventive Prosecution, 'Material Support' and the Role of the Judge after United States v. Mehanna," Boston College Law School Faculty Papers, 20 I2, Paper 392.

${ }^{14}$ Paul M. Barrett, Muslims in America: The Struggle for the Soul of a Religion (New York: Farrar, Straus, \& Giroux, 2007), 5.

is Brown, 26.

${ }^{16}$ Timothy Zick, The Cosmopolitan First Amendment (Cambridge: Cambridge University Press, 2013$), 6$. 
In his capacity as a representative of the US government, the prosecuting attorney in Mehanna's case offered his own view of legal boundaries and norms. He told the jury that while it is "not illegal to watch something on the television," it is illegal "to watch something in order to cultivate your desire, your ideology, your plots to kill American soldiers, or to help those, as in this case, who were." 17 Relying on charged, emotional language, and in effect calling on the jury to disregard the First Amendment in assessing Mehanna's guilt, the prosecutor created a precedent for treating the cultivation of an unpopular ideology as a crime, and suggested that reading a public document may be subject to legal sanction, depending on one's motivation (and, by implication, on one's ideology and religion). The prosecutor's assertion implies that, while it is permissible for people of certain beliefs (law enforcement officials, or, for example, non-Muslims) to read dangerous materials, the same material is forbidden to those with different beliefs.

As the prosecutor acknowledges, Mehanna was not accused of violent acts, or even of intending to commit such acts. The prosecution's strategy went beyond criminalizing intent. To the extent that it is illegal "to watch something in order to cultivate your desire [or] your ideology," criminality resides in the motives that accompany reading and watching, not in the acts themselves. Given that motives spring inseparably from beliefs, the prosecutor proposed to criminalize thought. Such (mis)readings of the law directly result from a post-9/ i I legal culture, which treats terrorism as a crime that must be preemptively addressed. As Attorney General Alberto Gonzalez stated in 2016, "we simply cannot and will not wait for these particular crimes to occur before taking action." 8 These documents demonstrate that the security agenda of the post-9/I I state is in tension with the free exercise of religion and the right to freedom of belief.

In addition to heralding a new phase in the legal interpretation and application of the First Amendment, Mehanna's ideological situation is distinctive in itself. As his sentencing statement (discussed in the next section) shows, Mehanna forges a chain of solidarity across racial and religious borders. When he addressed the judge and jury in a Boston courtroom following the announcement of his seventeen-year sentence, Mehanna also addressed a diverse cross-section of the American public, and situating himself within the American dissident tradition. His statement drew extensively on American ideologies, both violent and nonviolent, to justify his intellectual

17 United States v. Mehanna, No. 09-100 I7-GAO (D. Mass. 201 I), day 3, 38-39.

${ }^{18}$ Alberto Gonzales, "Remarks at the World Affairs Council of Pittsburgh on Stopping Terrorists before They Strike: The Justice Department's Power of Prevention," at www. usdoj.gov/ag/speeches/2006/ag_speech_060816.html. Gonzalez's statement is discussed in Robert Chesney, "Beyond Conspiracy? Anticipatory Prosecution and the Challenge of Unaffiliated Terrorism," Southern California Law Review, 80, 3 (2007), 425-502. 
trajectory. This American dissident trajectory, Mehanna argued, had brought him into conflict with US government. The relation that Mehanna triangulated, between US dissidence, government surveillance, and Muslim piety, calls on us to rethink the parameters of civil disobedience in post-9/I I America. In bringing liberal conceptions of freedom and agency into conflict and dialogue with religious conviction, Mehanna departs from society's mainstream secular liberalism and returns us to faith-based action.

\section{"IT'S BECAUSE OF AMERICA THAT I AM WHO I AM"}

On I2 April 2012, when his sentence was announced, Mehanna read a prepared statement that is suffused with a rhetoric suggesting an awareness of its own posterity. By virtue of its historical significance, as well as the range of its examples and the scope of its arguments, this document is a key text in the canon of American dissent, and an important primary source for American Islam in the post-9/ I I period. The testimony begins by explaining Mehanna's refusal to cooperate with the FBI agents who offered him the chance to become a collaborator in exchange for avoiding prosecution. His opening sets the tone for the narrative that follows:

Exactly four years ago this month I was finishing my work shift at a local hospital. As I was walking to my car I was approached by two federal agents. They said that I had a choice to make: I could do things the easy way, or I could do them the hard way. The "easy" way, as they explained, was that I would become an informant for the government, and if I did so I would never see the inside of a courtroom or a prison cell. As for the hard way, this is it. Here I am, having spent the majority of the four years since then in a solitary cell the size of a small closet, in which I am locked down for 23 hours each day.

Dramatically setting forth the events leading up to his arrest, Mehanna details the conflict with the state that ultimately resulted in his long-term incarceration. In presenting his version of the case, Mehanna persuasively argues that he was punished for his principled refusal to become an informant and to cooperate with the authorities.

Mehanna's claim is reinforced by the facts of the case: the most damning evidence against him was provided by a felon-turned-informant, who financed Mehanna's trip to Yemen (claimed by the government to have been in search of an al Qaeda training camp), and who later admitted to planning a terrorist attack in a US shopping mall. ${ }^{19}$ In exchange for immunity from prosecution,

19 Kareem Abuzahra was a co-collaborator who was granted immunity in order to testify in the case against Mehanna and was a key witness for the prosecution. However, as noted by several commentators, his testimony was compromised by his admission that he was willing to lie. See Brown, i 8. 
this individual agreed to testify against Mehanna. Due to this agreement, a man who plotted a terrorist attack against the United States remains unprosecuted (and indeed protected from prosecution) while Mehanna, who was never charged with planning such attacks, was punished with a seventeen-year prison sentence. After presenting himself as a scapegoat who refused to cooperate with the FBI, Mehanna dwells on his dual identity as a Muslim American.

I wasn't born in a Muslim country ... I was born and raised right here in America and this angers many people: how is it that I can be an American and believe the things I believe, take the positions I take? Everything a man is exposed to in his environment becomes an ingredient that shapes his outlook, and I'm no different. So, in more ways than one, it's because of America that I am who I am [emphasis added].

After affirming his American identity, Mehanna recounts coming of age as an Egyptian American learning about the world through the historical narratives he read in American public schools. Mehanna recounts how the Batman comic book series opened his eyes to the fact that "there are oppressors, there are the oppressed, and there are those who step up to defend the oppressed." As Mehanna grew older he found this paradigm confirmed in every narrative he encountered. "I gravitated towards any book that reflected that paradigm," Mehanna explains, "Uncle Tom's Cabin, The Autobiography of Malcolm X, and I even saw an ethical dimension to The Catcher in the Rye." Mehanna's account of American political history is structured by a tripartite ethical framework: the oppressed, such as enslaved African Americans; the oppressor; and those who, like radical abolitionist John Brown, defend the oppressed.

Mehanna invokes Harriet Tubman, Nat Turner, and John Brown for their "fight against slavery"; Emma Goldman and Eugene Debs for their advocacy of "struggles of the labor unions, working class, and poor"; the German-born Jew Anne Frank, persecuted and killed by the Nazis; Rosa Parks, Malcolm X, and Martin Luther King Jr. for organizing the "civil rights struggle"; the communist revolutionary Ho Chi Minh, who helped the Vietnamese "liberate themselves from one invader after another"; and, finally, Nelson Mandela, who fought South African apartheid. ${ }^{20}$ Ranging across the globe, these are key figures in progressive US middle-school curricula. ${ }^{21}$

More debatable in terms of historical accuracy, but revealing of his investment in American history, is Mehanna's take on Paul Revere's midnight ride.

20 "Tarek's Sentencing Statement," Appendix to Glenn Greenwald, "The Real Criminals in the Tarek Mehanna Case," Salon, I 3 April 20 I 2, at www.salon.com/20 I 2/04/ I $3 /$ the_real_criminals_in_the_tarek_mehanna_case. All future references are to the unpaginated text at this link. Mehanna's statement is available on numerous websites, including the dedicated website for Mehanna's case at http://freetarek.wordpress.com.

${ }^{21}$ See, for example, the lesson plans in Joy Hakim, Johns Hopkins University Teaching Guide and Resource Book (Oxford: Oxford University Press, 2005). 
Arguing that it was conducted in order to "warn the people that the British were marching to Lexington to arrest Sam Adams and John Hancock then on to Concord to confiscate the weapons stored there by the Minutemen," Mehanna treats Paul Revere's ride as an example of jihad. "There's an Arabic word to describe what those Minutemen did that day," he states. "It was a word repeated many times in this courtroom. That word is jihad." Mehanna here positions himself within the history of American dissidence, presenting it also as a history of violence. He also reclaims the term "jihad" while linking it to a progressive agenda, as many prominent Muslim Americans have done in recent years, partly in order to clarify the nonviolent aspects of its meaning. ${ }^{22}$

Mehanna's lineage of abolitionism, the labor movement, anti-Nazi mobilization, Jim Crow laws in the American South, and South African apartheid is at once cosmopolitan and conventional. This list of milestones could have been lifted from many US textbooks on world history. The major difference between his version of American history and the state-sponsored one is Mehanna's presentation of the American Revolution as a form of jihad against British imperialists. Mehanna may have been introduced to the figures he mentions while attending Lincoln-Sudbury Regional High School, yet he adds to a familiar rendering of American history an incipient Salafi Islamist activism that introduces a new struggle of the oppressed against their oppressors. Perhaps due to the United States' historical status as a primary military target for Islamic radicalism, the scope for reading Islamic dissent sympathetically in relation to the other Third World liberation movements has historically been minimized in US contexts. Against a dominant American version of world history that tends towards either indifference or hostility towards Muslim liberation movements, Mehanna's sentencing statement extends the range of American nonviolence by integrating Islamist dissent into its ethical core.

Mehanna's outrage at US-perpetrated injustice in Iraq, Afghanistan, and elsewhere in the Muslim world is familiar to any regular reader of the news, but his endeavor to link his own radicalism with dissident strands in American history strikes a more unusual note. From Martin Luther King Jr. to Gandhi, many activists critical of US politics prior to Mehanna have grounded their programs for political action in genealogies of American dissent. But transpiring as it does in a post-9/I I world that constructs Muslims and Americans as antagonists, Mehanna's combination of American dissidence and Muslim activism demands close attention. Mehanna's critique of American imperialism lays a narrative foundation for his status as an American dissident and complicates a US liberalism that has engaged in only limited ways thus far with Muslim points of view.

${ }^{22}$ For one such use of "jihad" see Amina Wadud, Inside the Gender Jihad: Women's Reform in Islam (Oxford: Oneworld, 2008), as well as below, n. 52. 
My discussion of Mehanna's case has three goals. First, I bring together the words and images through which Mehanna engaged with Henry David Thoreau. Second, I trace the implications of Mehanna's merger of Salafi Islamism with this American political thinker for our understanding of American intellectual history. Third, I consider how the controversies stirred by Mehanna's views and persecution make Thoreauvian modes of dissent meaningful within a post-9/I I world. Whereas, read on his own terms, Thoreau's early writing can be seen to support a withdrawal from politics, many subsequent engagements with Thoreau's writings have activated other latent possibilities within his political thinking. In registering the dissonance between what Thoreau likely intended and the meaning his words have since acquired, I clarify their ongoing relevance, as well as their relation to violence.

\section{WORDS AND IMAGES}

I will now turn to Mehanna's verbal and visual commentaries on his imprisonment, composed prior to his conviction in $20 \mathrm{I} 2$, while he was awaiting trial. Like nearly all prison literature, these texts traverse the threshold of public and private writing, making a general statement while bearing witness to an inner struggle. From the prison cell where he was held under solitary confinement from 2008 to 20I2, Mehanna gave visual form to his incarceration. Whereas Mehanna's visual work explicitly signals his debt to Thoreau, his sentencing statement only alludes to Thoreau indirectly, through the persona of abolitionist John Brown (1800-59). I will therefore first discuss Mehanna's handling of Thoreau's early essay on civil disobedience in his art before considering how Thoreau mediated Mehanna's encounter with John Brown in the sentencing statement.

At the top of Mehanna's sketch of life in prison is an inscription consisting of an extended citation from Thoreau's "Resistance to Civil Government" ( I 849), a text which later came to be known - to Gandhi, Hannah Arendt, Martin Luther King Jr., and the many others who have drawn sustenance from it - by the title "On Civil Disobedience." ${ }_{23}$ "Resistance to Civil Government" was composed in Concord, a mere eighteen miles away from Sudbury, the town where Mehanna grew up, and only four times further

23 "Resistance to Civil Government," was based on a lecture originally entitled "The Rights and Duties of the Individual in Relation to Government" (1848). The essay was first called "Civil Disobedience" in the posthumous edition of Thoreau's writings: $A$ Yankee in Canada, with Anti-slavery and Reform Papers (1866). See Nancy Rosenblum, "Introduction," in Henry David Thoreau, Political Writings, ed. Rosenblum (Cambridge: Cambridge University Press, 1996), vii-xxxi, xii. 
away from Springfield, the town where John Brown launched his abolition campaign.

In an early sketch prior to his trial, Mehanna portrayed a tableau consisting of rows of bricks towering over a prisoner. Graffiti selectively adorns the bricks' surface. The upper half of one wall is covered with a quotation from Thoreau, and the manner of inscription evokes Mehanna's confinement. Thoreau's words read as follows: "I could not help being struck with the foolishness of that institution which treated me as if I were mere flesh and blood and bones." 24 "If there was a wall of stone between me and my townsmen," Thoreau continues, "there was a still more difficult one to climb or break through before they could get to be as free as I was." Thoreau had good reason to minimize his confinement, and to stress its limited impact on his psyche, given that he was only imprisoned for one evening in the local Concord jail. Mehanna was incarcerated under different circumstances, yet he incorporated Thoreau's words into his graffiti: "I did not for a moment feel confined, and the walls seemed a great waste of stone and mortar" ("RCG," I 3). Although he faced a much longer incarceration, Mehanna's kinship with Thoreau is obvious. Their shared tendency to privilege the spiritual over the material reflects how both thinkers ground their political thought in religious conviction. "The state never intentionally confronts a man's sense, intellectual or moral, but only his body," Thoreau continues in Mehanna's citation. "It is not armed with superior wit or honesty, but with superior physical strength." The passage famously concludes with a mixture of defiance and a promise of peace: "I was not born to be forced. I will breathe after my own fashion" ("RCG," I4). Thoreau's insistence on the sovereignty of his conscience over the materiality of the state was to become a central platform of Mehanna's political theory.

Turning from the words to the image: sticks marking the passage of time cover the bottom four rows of bricks. A flower blooms above the bricks, inscribed with the words "FREE AAFIA." Mehanna here aligns himself with Aafia Siddiqui, a Pakistani neurologist currently serving a sentence of eighty-six years in solitary confinement in a Texas prison. The same year that he was sentenced, Mehanna wrote a short essay in which he recollected meeting Siddiqui in person. She was a "frail, limp, exhausted woman who could barely hold her own head up straight in a pale blue wheelchair." 25 The harshness of Siddiqui's sentence is due to what her sentencing judge

${ }^{24}$ Henry David Thoreau, "Resistance to Civil Government," in Thoreau, Political Writings, I-22, I 3. Future references to this text are given parenthetically in the text, with the abbreviation "RCG."

25 Tarek Mehanna, "The Aafia Siddiqui I Saw," in Dr. Aafia Siddiqui: Other Voices (Silver Springs, MD: Peace Thru Justice Foundation, 2012), 2 I. 
called "enhancements" for, among other things, terrorism. Siddiqui was convicted of attempting to kill her US interrogators when she was detained for questioning in Afghanistan. ${ }^{26}$ Taken from her Pakistan residence and arrested in 2008, Siddiqui was convicted in $2010 .{ }^{27}$ While media coverage has focussed on alleged ties to al Qaeda, the attempted murder for which Siddiqui was convicted is unrelated to such allegations. Aafia has acquired "iconic status" in some parts of the Muslim world as an exemplar of the hypocrisies of the US-led war on terror. ${ }^{28}$ Her case has received considerable media attention in Pakistan especially, and continues to strain US-Pakistan relations. In incorporating Aafia's story into his tableau of prison life, Mehanna affiliates himself with a transnational network of Islamist political prisoners who are incarcerated for their thoughts, publications, translations, and comments on internet forums.

To return to Mehanna's image: completing the visualization of arbitrary justice, Aafia's name is topped with the Arabic letters Lab), meaning "There is no God but God," the Islamic confession of faith. To the right of these words is a poster, partially obscured by the frame, which reads, "ADMINISTRATION SEGREGATION UNIT RULES: GIVE UP YOUR HUMANITY." Beneath this sign, as if to negate the directive above it, block letters spell the word NEVER. These words develop the Thoreauvian insistence on the sovereignty of the individual conscience over any nation's law. In a passage which Mehanna no doubt applied to his own situation, Thoreau called on the state to "recognize the individual as a higher and independent power from which all its own power and authority are derived" ("RCG," 2 I). When he insists on the absolute prerogative of the individual over the state, Mehanna is influenced as much by Thoreau's articulation of this prerogative as by the Muslim sources he cites at length in his social-media posts. ${ }^{29}$

Two rows below the quotation from Thoreau, a pair of outstretched hands reach towards a Quran. The sacred text is labeled as such in Arabic and English. To the left of these images are six prison bars (Figure I). When viewed together, the bars and the image at the bottom of three columns of stars and a white blotch trace, in purple and white lines, the US flag. The image of the flag captures the paradox Mehanna seeks to expose: the American Republic, created to protect life, liberty, and the pursuit of

\footnotetext{
${ }^{26}$ A chronology is given in Middle East Journal, 65, I (201 I), I 23 and 64, 3 (2010), 467.

${ }^{27}$ For a collection of accounts of what is known about Siddiqui's case see the articles listed by the New York Times at http://topics.nytimes.com/top/reference/timestopics/people/s/ aafia_siddiqui/index.html.

${ }^{28}$ Declan Walsh, "The Mystery of Dr Aafia Siddiqui," The Guardian, 24 Nov. 2009, at www. theguardian.com/world/2009/nov/24/aafia-siddiqui-al-qaida.

29 See the official Facebook page at www.facebook.com/FreeTarekMehanna.
} 


\section{COULD NOT HELP BEING STRUCK...}

? 1 1

".. I could not help being struck with the foolishness of that institution which treated me as if I were mere flesh and blood and bones, to be locked up... I saw that if there was a wall of stone between me and my townsmen, there was a still more difficult one to climb or break through before they could get to be as free as $T$. was. I did not for a moment feel confined, and the walls seemed a great waste of stone and mortar *- The state never intentionally confronts a man's sense, intellectual or moral, but only his body, his senses. It is not armed with superior wit or honesty, but with superior physical strengTh. I I was not bom to be forced. I will breathe after my lown fashion. Let us see who is strongester." Henry Davia

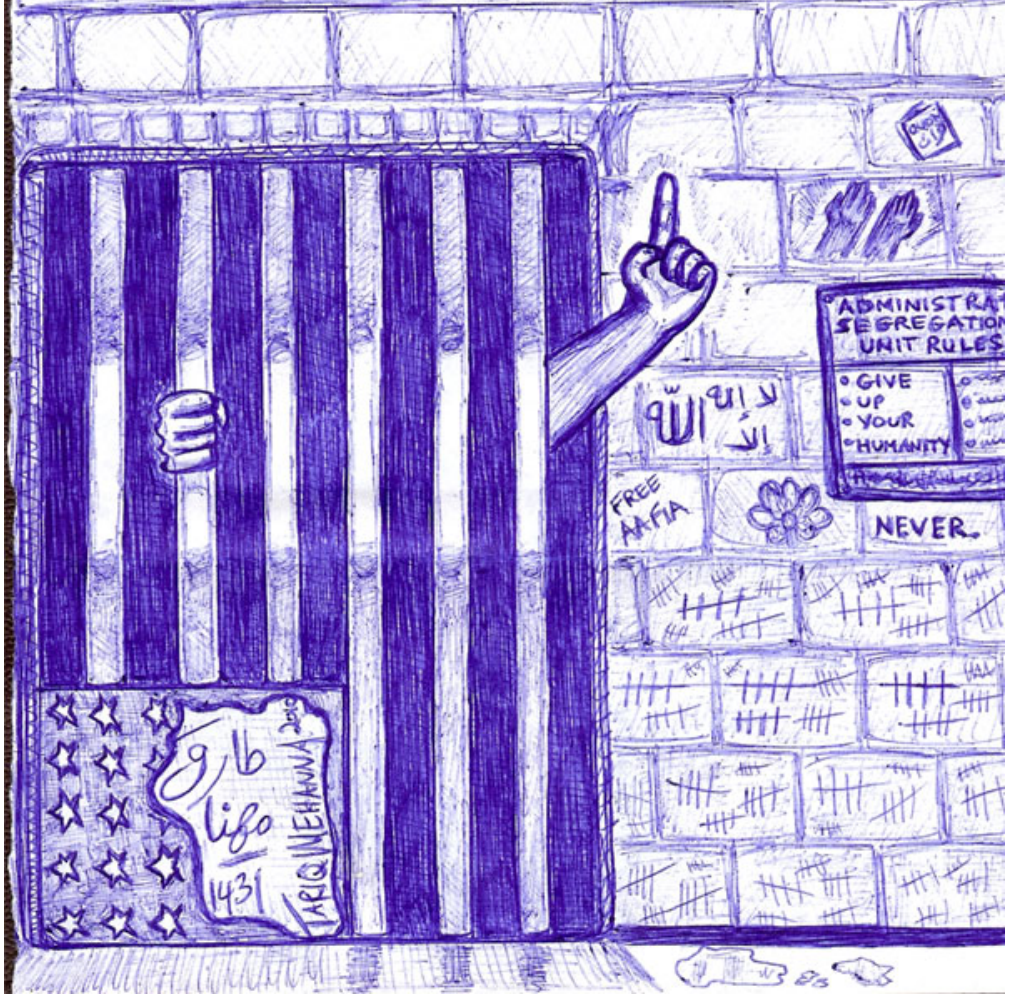

Figure I. Mehanna's prison sketch (2010). 
happiness, is now actively undermining these commitments by persecuting the free speech of its Muslim citizens.

Mehanna's verbal solidarity with Aafia is reinforced by a second sketch, entitled "Tribute to Aafia" (Figure 2). "The male and female believers are allies [awliya'] of one another" (al-Tawbah 9:7I), reads the inscription along the top. Although the first citation alludes to a suggestion of gender equality, the Quranic citation beneath those words reinforces patriarchal difference: "Men are the protectors and maintainers of women" (al-Nisa 4:34). Both citations are given in Arabic, followed by English translation. The first quotation participates in a growing trend within American Islam to bring transnational feminism into conversation with Muslim learning, while the second reinstates a patriarchal hierarchy. ${ }^{\circ}$

Like the flag that adorns the bottom right corner of the sketch, representing the persecution of Muslim Americans, Mehanna's citations serve a dual purpose: they protest injustice while appropriating a history of American dissent. In her exegesis of Thoreau's political theory, political theorist Leigh Jenco documents how, carried to its logical conclusion, Thoreau's political theory could be seen to underwrite a withdrawal from the political realm. While for Thoreau "physical coercion is both necessary and sufficient for the enforcement of political obligations," writes Jenco, the state's reversion to force "is at odds with the holistically perceived higher law that grounds Thoreau's moral duty." ${ }_{31}$ When Mehanna uses Thoreau to advocate a civil disobedience that privileges the individual over the masses as the locus of political protest, he adapts this form of dissent to a Muslim American reality, through a process that transforms both elements in this compound identity. This individualist orientation brings Mehanna even closer to Thoreau's conception of civil resistance than the more collectively focussed forms of civil disobedience articulated by Martin Luther King Jr. and Gandhi. In the passage cited by Mehanna, Thoreau argues that no coercion from the state can override the individual's ethical prerogative. Unlike Thoreau, King regards the resistant body as a primary locus of political resistance. By contrast, Thoreau and Mehanna focus on the work of the individual conscience in critiquing the state. Their shared rejection of the state's claims to legitimacy aligns Mehanna to Thoreau and contrasts with the collectivism of King and other civil rights activists.

30 See, for example, Asma Barlas, "Believing Women" in Islam: Unreading Patriarchal Interpretations of the Qur'an (Austin: University of Texas Press, 2002).

${ }^{31}$ Leigh Kathryn Jenco, "Thoreau's Critique of Democracy," Review of Politics, 65, 3 (2003), $355^{-8} \mathrm{I}, 364$. 


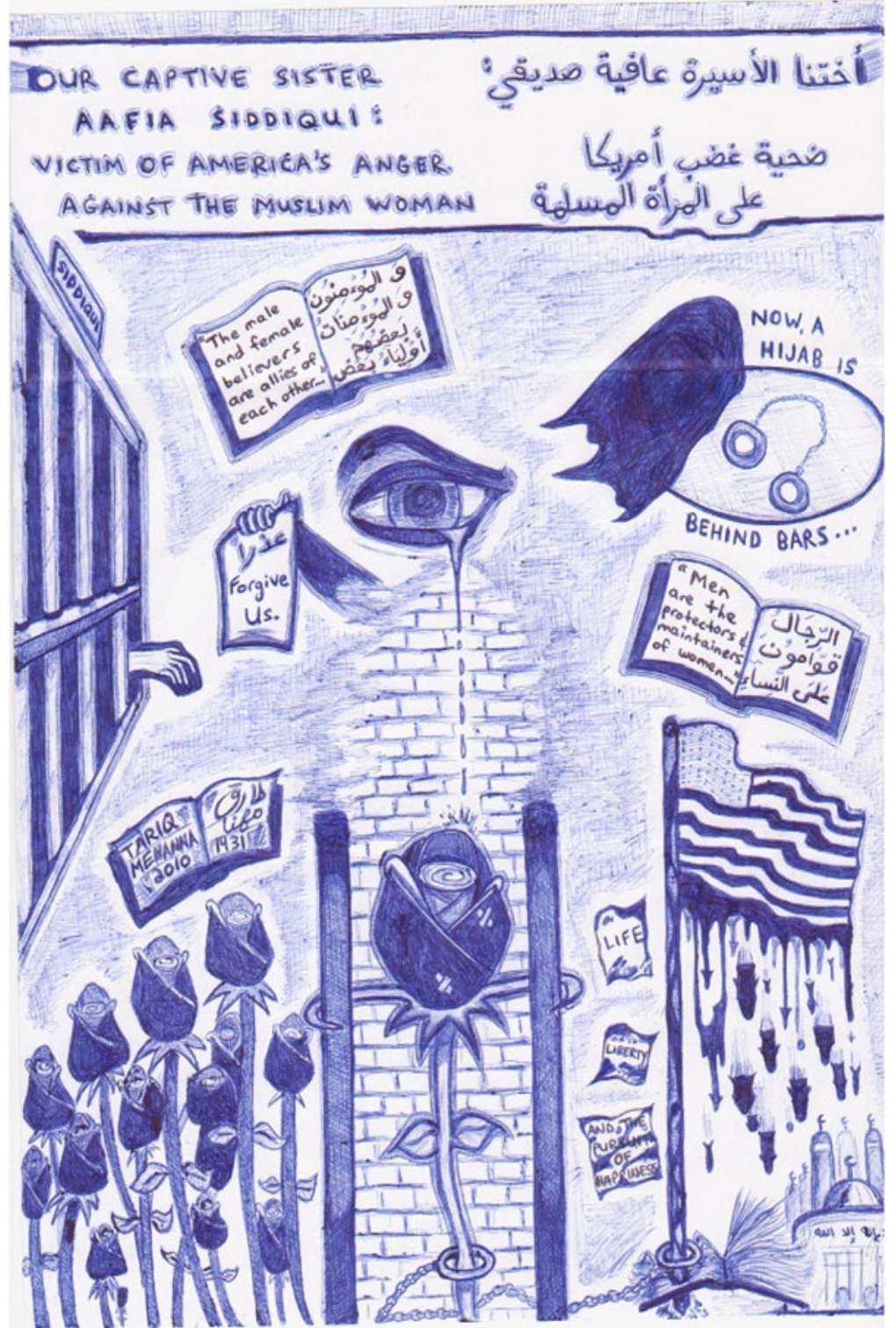

Figure 2. Mehanna, "Tribute to Aafia."

Thoreau memorably wrote in the essay quoted by Mehanna, "law never made men a whit more just; and, by means of their respect for it, even the well-disposed are daily made the agents of injustice" ("RCG," 3). Thoreau's insistence on the ethical limits of the law finds its way directly into 
Mehanna's political thought, which converges and stands in tension with older currents within Islamic thought that similarly validate a higher law, shari 'a. Although classically shari 'a denoted a form of law that incorporated all aspects of human existence, for most modern Muslims shari 'a signifies primarily "a spiritual resource, a connection with God, and a way to discipline the inner self." 32 Mehanna is troubled by what Hallaq refers to as the "evisceration" of shari 'a in modernity, wherein it has come to reference a primarily private realm. Like many Salafis, and Islamic modernists generally, he wishes to situate shari a more publicly, such that it can ground political decisions and thinking. Yet, as Hallaq also recognizes, any attempt to modernize shari $a$ in this way is fraught with contradiction, because Islamic law originally developed in a world that thought differently about the relation between public and private spheres. ${ }^{33}$ Whereas in classical Islamic thought the individual conscience lacks sovereignty, it plays a more decisive role within Thoreauvian political theory, and in most strands of American political thought that have developed from this beginning. ${ }^{34}$ Mehanna's dialogue between Salafism and Thoreauvian political theory transpires within this this maze of contradictions.

Against this analogy between American transcendentalism and Mehanna's Salafi modernism, it might be objected that Thoreau did not directly endorse violence (although he did endorse a perpetrator of violence, John Brown). On these grounds, Mehanna's use of Thoreau to elaborate his version of justice might be seen as a selective interpretation. It is true that "Resistance to Civil Government" presents a largely negative account of political action, and dwells more concretely on the dangers of acting wrongly than on the means and strategies for acting rightly. Additionally, and arguably in contradistinction to Mehanna, Thoreau defends the legitimacy of avoiding politics tout court. Thoreau states,

It is not a man's duty, as a matter of course, to devote himself to the eradication of any, even the most enormous wrong; he may still properly have other concerns to engage him; but it is his duty, at least, to wash his hands of it, and, if he gives it no thought longer, not to give it practically his support. ("RCG," 7)

32 Wael Hallaq, The Impossible State: Islam, Politics, and Modernity's Moral Predicament (New York: Columbia University Press, 2013), x.

${ }^{33}$ See Talal Asad, Thinking about Secularism and Law in Egypt (Leiden: International Institute for the Study of Islam in the Modern World, 200I).

${ }^{34}$ I do not intend to suggest that classical Islamic thought has nothing to say about the individual conscience, just that there is a difference in emphasis, and that Thoreau, rather than Islam, is closest to Mehanna in terms of his approach. For a discussion of the individual conscience in Islam grounded in classical sources see M. Mujeeb, "The Status of Individual Conscience in Islam," Studies in Islam, 7, 3 (1970), 125-49. 
While not an explicit rejection of violence or of direct political action, this passage can be read as a justification for withdrawal from the political realm. However, Thoreau's vision of the appropriate grounds for political action should inform our understanding of the circumstances under which this essay was composed, including the night Thoreau spent in jail for his civil disobedience. Thoreau acted without drawing attention to his dissidence. It is legitimate to avoid politics, Thoreau believed, so long as this avoidance does not increase another's suffering. Paying a poll tax to support an unjust war, in this case the Mexican-American War (1 846-1 848), as the US government required him to do, was for Thoreau unconscionable. 35

\section{ABOLITIONIST AND SALAFI MILITANCY COMPARED}

The ideology underlying Mehanna's controversial views on violence also echoes the actions of another crusader against US-perpetrated injustice whom Thoreau, more than any other American writer, memorialized: the abolitionist John Brown. More than I 50 years after his death, Brown remains a controversial hero. His ethics of bloodshed, like Mehanna's, leave little room for mercy. Brown's legacy closely parallels that of Mehanna, not least because of the links between his Christian fundamentalism and Mehanna's Salafism. Brown famously led a violent slave uprising at Harper's Ferry in I 859 , and was soon afterwards publicly hung. Like Mehanna, Brown endorsed violence as a means of resisting extreme injustice. Prior to leading the slave rebellion in Harper's Ferry, Brown oversaw the killing of five white settlers in the slave-owning settlement of Pottawatomie Creek, Kansas. ${ }^{36}$ (Notably, it was for his organization of the uprising, rather than for these murders, that Brown was hung; the former was considered action against the state and therefore subject to capital punishment.) Mehanna stands accused of no such violent crime. Both activists, however, share a concern with social justice, and believe that attaining social justice may require violence, whether exercised by them or by others. Mehanna's explicit identification with Thoreau in his sketch and with Brown in his sentencing statement further links the two figures.

On 30 October I 859 , one day before the jury's sentence of death by hanging for Brown, Thoreau mounted the platform of the town hall in Concord,

35 For further on Thoreau's support of political activism in relation to his skepticism towards politics see Jonathan Mckenzie, "How to Mind Your Own Business: Thoreau on Political Indifference," New England Quarterly, 84, 3 (201 I), 422-43.

${ }^{6}$ Zoe Trodd, "Writ in Blood: John Brown's Charter of Humanity, the Tribunal of History, and the Thick Link of American Political Protest," Journal for the Study of Radicalism, I, I (2007), I-29, 4 . 
Massachusetts to deliver the speech called "A Plea for John Brown." In this and in a later essay written for Brown's memorial service, Thoreau discussed Brown's rebellion as "a revolution in behalf of another and an oppressed people." 37 Thoreau's endorsement of Brown's raid indicates an evolution in his thinking about violence and nonviolence beyond his earlier essay of I 849, and reveals common ground between Thoreauvian political theory and Muslim militancy. As Turner suggests in his reading of Thoreau, conjoining aesthetic and legal theory can make of civil (or uncivil) disobedience a "public statement through the artistic re-creation of the act of refusal and public meditation on its significance." 38 Stated otherwise, Thoreau and Mehanna made their private consciences publicly political through their words and images.

Although Thoreau and Brown parted ways on many substantive issues, Thoreau's memorialization of Brown and his efforts to save him from execution reveal an important dimension of his intellectual agenda. Thoreau praises Brown as "a superior man" who "did not value his bodily life in comparison with ideal things" ("PJB," I 47). The ideal dissident, in Thoreau's understanding, is willing to lay down his life for his beliefs. Thoreau also praises Brown for recognizing that the individual is "the equal of any and all governments" ("PJB," I 47). Revealing a kinship with Brown's Calvinism, Thoreau implicitly acknowledges that there are occasions when violence is the only legitimate and viable form of resistance. ${ }^{39}$ In maintaining that individual conscience will ultimately prevail over the state's violence, Thoreau and Mehanna cultivate a sovereign human conscience, which they consider more efficacious than bodily protest. Thoreau refers to this conscience as the "higher law"; for Mehanna, it is shari ' $a$. For both, this ethical hierarchy defines their respective positions within the American dissident tradition. The respective distance of Mehanna and Thoreau from the teachings of Gandhi and Martin Luther King Jr. regarding the efficacy of nonviolence is linked to their greater openness to violence and, ultimately, to their more militant politics.

Brown's concept of the sovereignty of the individual conscience was observed and appreciated by Emerson as well, following the former's visit to

37 Henry David Thoreau, "A Plea for John Brown" (1859), in Thoreau, Political Writings, I 37-58; and Thoreau, "The Last Days of John Brown" (I860), in ibid., I63-69. Future references to these essays are given parenthetically in the text, with the abbreviations "PJB" and "LDJB."

${ }^{8}$ Jack Turner, "Performing Conscience: Thoreau, Political Action and the Pleas for John Brown," Political Theory, 33, 4 (2005), 448-71, 467.

39 For a suggestive account of the political dimensions of New England Puritanism that informs this reading of Thoreau and Brown see Michael Walzer, The Revolution of the Saints: A Study in the Origins of Radical Politics (Cambridge, MA: Harvard University Press, 1965). 
Concord on a lecture tour. According to Emerson, Brown believed that "one good, believing, strong-minded man is worth a hundred, nay twenty thousand men without character, and that the right men would give a permanent direction to the fortunes of a state." $4 \circ$ Neither Thoreau nor Emerson dwelt on their substantive divergences from Brown, and equally, neither advocated violence. Their support of Brown was strategic: they saw it as a means of bringing slavery to an end, and of forestalling and delegitimizing Brown's execution. As Truman John Nelson notes, the chronology of Thoreau's stand for Brown ought to inform its interpretation: "it took place before Brown had had his day in court ... and inevitably made his death a martyrdom." ${ }^{41}$ In defending Brown, Thoreau was also defending the principle of "innocent until proven guilty," and asserting his right to defend unpopular voices in the name of justice. It was an alliance forged from adversity. Yet a century and a half later, parallels between Thoreau's approach to violence and militant socialjustice agendas like Mehanna's are increasingly evident.

Brown insisted that "any man more right than his neighbors constitutes a majority of one" ("RCG," 9). All three thinkers - Thoreau, Brown, and Mehanna - vest their faith in the sovereignty of the individual. From their point of view, even one righteous person who practices justice is adequate to shift the balance of right and wrong. Brown raided a US government arsenal with only twenty-one men in his "battalion," yet persuaded that his cause would triumph. Thoreau viewed with contempt the pragmatism of his contemporaries, who judged Brown crazy. In a speech he read at Brown's funeral, Thoreau pointed out that if Brown had "gone with five thousand men, liberated a thousand slaves, killed a hundred or two slaveholders, and had as many more killed on his own side, but not lost his own life, these same editors would have called [his rebellion] by a more respectable name" ("LDJB," I66). Brown's willingness to live and to die for a cause in defiance of mainstream liberal politics gives the dissident spiritual leverage over the state responsible for his incarceration. In Thoreau's view, this spiritual prerogative (which he calls "the higher law," anticipating Mehanna's conception of shari 'a) is the source of the dissident's power. Mehanna's writings from prison rely heavily on this concept of an individual conscience acting upon a higher law.

$4^{\circ}$ Ralph Waldo Emerson, Journals of Ralph Waldo Emerson, 1820-1876, Volume IX, ed. Edward Waldo Emerson and Waldo Emerson Forbes (Boston and New York: Houghton Mifflin Company, 1913), 82.

4 Truman John Nelson, "Thoreau and John Brown," in The Truman Nelson Reader, ed. William John Schafer (Amherst: University of Massachusetts Press, 1989), 195-21 5, 195, original emphasis. 
In defending Brown's character, Thoreau compares him with the American revolutionaries of 1776 , expressing the same admiration that Mehanna felt for figures like Paul Revere. Whereas the 1776 Revolutionaries "could bravely face their country's foes," Brown "had the courage to face his country herself, when she was in the wrong" ("PJB," I 38 ). As Turner notes, "What Thoreau most admires about Brown is his willingness to hold not simply America's enemies to moral account, but America itself." 42 Thoreau's own practice of holding America to account no doubt served as a model for Mehanna, who also cited US violence as a basis for his opposition to his government. His sentencing statement referenced the massacre perpetrated by Sergeant Robert Bales, who killed sixteen Afghan women and children while on a tour of duty in Kandahar in 20I2. "When Sgt. Bales shot those Afghans to death," stated Mehanna, "all of the focus in the media was on him - his life, his stress, his PTSD, the mortgage on his home - as if he was the victim. Very little sympathy was expressed for the people he actually killed." Controversially, Bales was tried in a military court in the United States, rather than in Afghanistan, among those who most directly suffered from his crime. Bales was sentenced to life in prison, without parole.43

Mehanna's sentencing statement contains other allusions to Thoreau, particularly to the latter's writing on John Brown. For example, Thoreau insisted that Brown "could not have been tried by a jury of his peers because his peers did not exist" ("PJB," I 47). Similarly, Mehanna follows his discussion of Bales in the sentencing statement with the claim that the media's biases imperil the integrity of the justice system, making it impossible for a jury to deliver a just verdict. "I wasn't tried before a jury of my peers," Mehanna states, "because with the mentality gripping America today, $I$ have no peers. Counting on this fact, the government prosecuted me - not because they needed to, but simply because they could" (emphasis added). Mehanna here compares his own prosecution to that of John Brown, as filtered through Thoreau's writings. Implicating Thoreau in this conversation introduces a new dimension. Both Mehanna and Brown openly advocate violence in ways Thoreau did not, and both do so on religious grounds. Each dissident regards his conscience as sovereign. They thereby elevate their political convictions and chosen faith

42 Turner, 454.

${ }^{43}$ For a discussion of Bales's case from the point of view of legal theory see Michael D. Smith, "Mapping the Geolegalities of the Afghanistan Intervention," in Irus Braverman, Nicholas Blomley, David Delaney, and Alexandre Kedar, eds., The Expanding Spaces of Law: A Timely Legal Geography (Stanford, CA: Stanford University Press, 2014), 142-66. Bales has recently accounted for his actions in an interview for $G Q$ with Brenden Vaughn: "Robert Bales Speaks: Confessions of America's Most Notorious War Criminal," at www.gq.com/story/robert-bales-interview-afghanistan-massacre, accessed 20 Nov. 2017. 
over the laws of the state, which for them is based on precarious ethical foundations.

"Resistance to Civil Government" was not the only work in which Thoreau set forth his views on the conditions under which rebellion against the state is both legitimate and necessary. Ten years after delivering "Resistance to Civil Government" to the Concord community, Thoreau called an assembly in Concord's town hall to plead for John Brown. He had been disturbed by reports that, following Brown's raid, some of his Massachusetts neighbors had begun to advocate for his execution. Thoreau was determined to contest their vilifications. As his biographer reports, Thoreau was "instantly, totally caught up in the passion of the moment" and "decided to make a public speech to right the imbalance" of the public sentiment that was turning against Brown. ${ }^{44} \mathrm{He}$ rang the bell himself to call the meeting to order when the town's selectman whose job it was to ring the bell for such meetings refused. Thoreau then proceeded to offer a plea to his neighbors, not, as he clarified, in the hopes of saving his subject's life, which, as any realist could have seen, was already forfeited, but rather for the sake of saving Brown's "character, - his immortal life" ("PJB," I 56 ).

Compared to his speech on Brown at Concord's town hall, Thoreau's earlier refusal to pay the poll tax to fund the Mexican-American War was a passive act of resistance. Thoreau was only jailed because of his unintended encounter with a tax collector. Although Thoreau acted with political conviction, his journey to jail was not intentional; nor was his release, which was secured by a friend who paid his taxes on his behalf. The political implications of such passive action are limited; waiting for specific circumstances is obviously not the most effective way of overturning existing political norms.

By contrast, Thoreau's plea for John Brown was an act of mobilization. Thoreau's attempt to persuade his neighbors of the justness of Brown's cause was possibly his most political act. Not yet a theory of violence, Thoreau's "Plea for John Brown" is a program for revolutionary political action. It proposes to overturn the existing social order, however gradually. While "Resistance to Civil Government" argues that every citizen is obliged to avoid perpetuating evil through nonviolent means, by 1859 , in a state of mounting frustration over the continuation of slavery, Thoreau was ready to acknowledge that under the right circumstances, political violence may be legitimate and necessary for combating injustice.

Not everyone is obliged to engage in political violence, but when conscience dictates and when the cause is just, Thoreau accepts this form of dissent. While

${ }^{44}$ Robert D. Richardson, Henry Thoreau: A Life of the Mind (Berkeley: University of California Press, 1986), 370. 
praising Brown's character, Thoreau reflects on the appropriate scope of political action, including the conditions under which violence is justified. "It was [Brown's] peculiar doctrine," Thoreau writes, "that a man has a perfect right to interfere by force with the slaveholder, in order to rescue the slave. I agree with him" ("PJB," I 53). This acknowledgment that force is legitimate under certain conditions highlights an unresolved ambiguity in Thoreau's concept of civil disobedience, which in part accounts for its range of appropriations, from the pacifism of Tolstoy and Gandhi to the militancy of Mehanna. ${ }^{45}$ The strategy Thoreau followed when he refused to pay the poll tax did not exhaust the range of legitimate political options. Political theorists who treat Thoreau as primarily or exclusively a theorist of nonviolence miss these incendiary dimensions of his political thought. Thoreau's ambivalence towards violence (more than his more publicized rejection of it) is part of what makes him relevant to Mehanna, who came of age in a country that, with respect to conflicts in the Middle East, had demonstrated a preference for short-term violence over a longer-term quest for peace.

Four months before his conviction, Mehanna circulated a series of quotations he had been collecting on the topics of violence, terrorism, freedom, the law, and prison. He had extracted these quotations from the writings and speeches of Malcolm X, Howard Zinn, Robert Fisk, Usama bin Laden, Sayyid Qutb, and Thoreau, indicating his source in each case. This is an eclectic but carefully selected list; US radicalism and Islamic dissent are closely intertwined in Mehanna's thinking. Mehanna prefaced the collection with the remark that the quotations were "selected from various books I have with me in my cell that I feel to be relevant to my trial in one way or another." ${ }^{6}$ One of the Malcolm X quotations directly touches on the legitimacy of violence: "I don't go along with anyone who wants to teach our people nonviolence until someone at the same time is teaching our enemy to be nonviolent." 47 Although Thoreau is typically remembered as a pacifist who retreated to his home by Walden Pond instead of entering the political arena, the militancy expressed in his writings and speeches on Brown directly anticipates Mehanna's approach to violence against the state.

4s Gandhi, for example, claimed that "until I read that essay I never found a suitable English translation for my Indian word, Satyagraha ... There is no doubt that Thoreau's ideas greatly influenced my movement in India." Quoted in George Henrick, "Influence of Thoreau and Emerson on Gandhi's Satyagraha," Gandhi Marg, July 1959, 165-78, 166.

46 "Tarek Mehanna: A Selection of Timely Quotes," at https://freetarek.wordpress.com/ 2012/01/09/tarek-mehanna-a-selection-of-timely-quotes, accessed is Nov. 2017.

47 Malcolm X, By Any Means Necessary (New York: Pathfinder, 1992), I60. 


\section{A MUSLIM AMERICAN PROJECT}

While its Islamic inflection is obvious, Mehanna's thinking opens a new chapter in the intellectual history of American radicalism. As Mehanna insisted in his sentencing statement, "It's because of America that I am who I am." This text, which is destined to become a foundational document within the history of American Islam, integrates a Muslim American identity into the American project. Emma Goldman, Anne Frank, and Nelson Mandela all feature as predecessors for Mehanna's conception of political action. Mehanna's approach is characterized above all by syncretism, and his insistence on the sovereignty of the individual conscience over the laws of the state is distinctively Thoreauvian. Indeed, Mehanna affirms that he gleaned his eclectic dissident history from his public education, and underscores that his worldview looks beyond his specific religion. "With each struggle I learned about," he recounts, "I found myself consistently siding with the oppressed, and consistently respecting those who stepped up to defend them regardless of nationality, regardless of religion" (emphasis added).

When, in 2013 , Mehanna was awarded the Sacco and Vanzetti Social Justice Award by the Community Church of Boston, named for Nicola Sacco and Bartolomeo Vanzetti, two Italian-born anarchist immigrants who were wrongfully convicted for murder and electrocuted in 1928, the award committee implicitly linked his Muslim activism to the history of American radicalism. ${ }^{48}$ The Sacco and Vanzetti Commemoration Society made the link explicit when they published a speech by Laila Murad of the Tarek Mehanna Defense Committee on their website entitled "Yesterday Sacco and Vanzetti; Now Tarek Mehanna." 49

Mehanna's eclectic dissident genealogy, combined with his belief that solidarity along the lines of class, race, and conviction runs even deeper than religious affiliation, is one version of a distinctive yet heterogeneous American Islam that is increasingly visible within American culture, albeit in undertheorized ways..$^{\circ}$ While Mehanna's Salafi interpretation of classical sources is but

${ }^{8}$ Sara Mulkeen, "Sudbury Man Convicted on Terrorism Charges Receives Award," MetroWest Daily News, 6 Jan. 2013, at www.metrowestdailynews.com/news/xio58227140/Sudburyman-convicted-on-terrorism-charges-receives-award\#ixzz2 $\mathrm{HMQPaH}_{3} \mathrm{Q}$. For the Sacco and Vanzetti case and background see Paul Avrich, Sacco and Vanzetti: The Anarchist Background (Princeton, NJ: Princeton University Press, I991).

49 See http://saccoandvanzetti.org/sn_displayı.php?row_ID $=73$. The speech was delivered in Boston on 22 Aug. 2010.

so Studies that showcase the diversity of American Islam include Zareena Grewal, Islam Is a Foreign Country: American Muslims and the Global Crisis of Authority (New York: New York University Press, 2013); and many of the essays in Juliane Hammer and Omid Safi, eds., The Cambridge Companion to American Islam (New York: Cambridge University Press, 2013). 
one of many voices in the diverse confessional landscape of contemporary Islam, his persecution by US authorities is the prism through which many American Muslims have come to experience what Thoreau called, with more than a small dose of irony, our "civil government."

One of the more eloquent testimonies to what Egyptian American writer Leila Ahmed has called the "quiet revolution" of American Islam is the commencement address delivered to Harvard's graduating class of 2002 by thensenior and president of Harvard's Islamic society Zayed Yasin. In a speech boldly entitled "My American Jihad," for which Yasin received a death threat purely on the basis of its title before the text of the speech was released, the Muslim American informed Harvard's graduating class of his personal affection for both the Quran and the US Constitution. Yasin's title was chosen in order to reclaim the original meaning of jihad as spiritual struggle from later, more militant, interpretations. ${ }^{51}$ "As a Muslim and as an American," stated Yasin, "I am commanded to stand up for the protection of life and liberty, to serve the poor and the weak, to celebrate the diversity of humankind." ${ }_{52}$ Yasin added that no "combination of faith, culture and nationality [that endorses] a community of the human spirit" could see a "contradiction" between the ethical claims of the US Constitution and the Quran. A similar reclamation of the word "jihad" occurs in Linda Sarsour's keynote speech at the Islamic Society of North America convention in 2017, which was rapidly picked up by the conservative media as posing a terrorist threat. ${ }^{53}$ Although Mehanna struck a different balance between Islamic dissent and American radicalism that brought him closer to the violent abolitionism of John Brown, each of these examples reveals Muslim Americans bringing "American" and "Islam" into a new kind of union. From the perspective of American history, and of the history of Islam in America, it is notable that Mehanna and Yasin are exact contemporaries, both born in 1980 .

${ }^{51}$ For the controversy preceding the speech see, among numerous media sources, "Free Speech: Testing," Harvard Magazine, July-Aug. 2002, 64-69, 64.

52 Cited and discussed in Leila Ahmed, $A$ Quiet Revolution (New Haven, CT and London: Yale University Press, 201 I), 234. The full text of the speech is reprinted, under the changed title "Of Faith and Citizenship," in the Harvard Magazine, July-Aug. 2002, 65, and at http://harvardmagazine.com/2002/07/of-faith-and-citizenship.html.

53 Samantha Schmidt, "Muslim Activist Linda Sarsour's Reference to 'Jihad' Draws Conservative Wrath," Washington Post, 7 July 2017, at www.washingtonpost.com/news/ morning-mix/wp/2017/07/07/muslim-activist-linda-sarsours-reference-to-jihad-draws-conservative-wrath/?utm_term=.422b6eb9ra 84 . The fifteen-year gap between these two example, both of which caused tremendous controversy and placed the speakers in grave danger, indicates that, unfortunately, no progress has been made in terms of educating the general American public regarding the meaning of "jihad." 


\section{Rebecca Ruth Gould}

The foregoing is not intended to suggest that Mehanna's views ought to be embraced. Mehanna's uncritical relation to many aspects of the Muslim tradition is worth noting, as is his lack of interest in recognizing the contingency of the historical and political processes through which his readings of classical Islamic sources have been formed. Many commentators have made these points, from both secular and Muslim perspectives, have recognized the contingency of these processes within their broader analyses of Salafism. ${ }^{54}$ Mehanna endorsed violence, often uncritically, in ways that are not clearly aligned with Islam and that have broader social-justice implications. ${ }^{55}$ For example, during the trial, the jurors were presented with a photo of Mehanna celebrating with friends in front of Ground Zero. Although such visual evidence can be interpreted in many ways, the prosecutor used this material to argue that Mehanna took an infantile delight in the deaths of the victims of the World Trade Center attack. ${ }^{56}$ It is difficult to determine where to situate such anecdotal detail within Mehanna's broader political thinking, yet such evidence places him at a distance from Brown, whose nobility of character was such that, in Thoreau's words, in "teaching us how to die" he "taught us how to live" ("LDJB," I 54).

A civil society such as the one Thoreau advocated for must guarantee the right to dissent from the political mainstream without risk of imprisonment. I have reserved my critique of Mehanna's embrace of violence in order to better understand his position within the history of American dissent that was largely founded by Thoreau and the abolitionists. Mehanna's case is one of many that reveals how the US justice system's cooptation by the war on terror has shifted the jurisdiction of the state and rearranged relations between public and private spheres. This cooptation has also exposed tensions internal to the liberal political imagination, which claims to be grounded in tolerance yet all too frequently refuses to give its opponents space for free expression when irresolvable antagonisms shape public debate. ${ }^{57}$

${ }^{54}$ Many recent studies contribute to various lines of critique, including Henri Lauzière, The Making of Salafism: Islamic Reform in the Twentieth Century (New York: Columbia University Press, 2015); Alexander Thurston, Salafism in Nigeria (New York: Cambridge University Press, 2016); Joas Wagemakers, Salafism in Jordan: Political Islam in a Quietist Community (New York: Cambridge University Press, 2016); and Laurent Bonnefoy, Salafism in Yemen: Transnationalism and Religious Identity (Oxford: Oxford University Press, 2012).

ss See, for example, his appeal to Osama bin Laden as "my real father," discussed in Innokenty Pyetranker, "Sharing Translations or Supporting Terror? An Analysis of Tarek Mehanna in the Aftermath of Holder v. Humanitarian Law Project," American University National Security Law Brief, 2, 2 (201 2), 2 I-42, 2 I.

${ }_{56}$ United States v. Mehanna, day 3, 39, cited in Brown, "Notes on a Terrorism Trial," 5.

57 In support of this point see the important critique of tolerance by Wendy Brown, Tolerance in the Age of Identity and Empire (Princeton, NJ: Princeton University Press, 2008). 
Instead of imprisoning those we disagree with, let me conclude by offering an alternative, drawn from a different intellectual tradition than that invoked thus far. In place of the classical liberal attempt to eradicate difference through John Rawls's concept of overlapping consensus, political theorist Chantal Mouffe proposes "agonistic pluralism" as a framework wherein "conflicts can take the form of an agonistic confrontation among adversaries." 58 Agonistic pluralism turns antagonism into agonism, and violence into disagreement. Violence does not thereby disappear, but it is mediated, debated, and engaged, and thereby made consistent with coexistence. Agonistic pluralism incentivizes democratic speech and neutralizes the appeal of violence. This framework for managing radically opposed points of view approaches ideological difference in a way that keeps these differences in tension rather than suppressing or privileging a single point of view. Hence agonistic pluralism is eminently suited to managing the tensions that Mehanna's Americanstyle Salafism would necessarily create within any diverse liberal society, such as the contemporary US. Mouffe's agonistic pluralism offers a more promising strategy for engaging with political and religious ideologies that are hostile to the state than does the post-9/ I I legal system's practice of preemptively criminalizing, and incarcerating, dissent.

Mehanna's objections to US actions abroad call for debate. In the absence of incitement to violence, incarceration is counterproductive. The moral challenges posed by the bombing of Iraq, Afghanistan, and even (via drones) Pakistan, as well as the war on terror within US borders, offer a parallel in certain respects the moral challenge posed by slavery in the nineteenth century. Thoreau made clear that he perceived violence as the best course of action in response to slavery in 1859 , and thereby revealed a potential affiliation between his political theory and Mehanna's jihadist embrace of violence. As at the height of slavery, the public remains by and large passive in the face of their government's excessive use of force. Now, as then, the majority prefers a problematic status quo to an uncertain peace. Now, as then, there are many reasons why an impassioned activist might become impatient with nonviolent protest, and might be persuaded of the necessity of violent action.

I have undertaken to show how, notwithstanding his alienation from, and persecution by, the United States, Tarek Mehanna defines himself as an American dissident. His intellectual genealogy began in Boston rather than Egypt, and was first awakened by reading Harriet Beecher Stowe, Malcolm $\mathrm{X}$, and J. D. Salinger rather than ideologues of the Muslim Brotherhood such as Sayyid Qutb and Hassan al-Banna. Mehanna's many frames of reference recalibrate existing alignments between various schools of political

${ }^{8}$ Chantal Mouffe, The Democratic Paradox (London: Verso, 2000), i 17. 
thought and various cultural traditions. That Mehanna's relation to violence is uncritical is a weakness in his thought, but it is not a crime. Mehanna speaks from within an American cultural milieu because he is American. Given Thoreau's description of John Brown as "the most American of us all" because he stood up for "the dignity of human nature" ("PJB," I 47), it is easy to see why Mehanna chose to juxtapose Thoreau's essays to the Quran when sketching the view from his prison cell.

Scholars within American studies and beyond have recognized that the global circulation of knowledge requires us to become acquainted with an increasingly "innumerable number of archives" formerly excluded from purview in order to plumb the relevance even of such canonical texts as the essays of Henry David Thoreau. 59 In the wake of this global turn, which shapes our disciplines as well as our daily lives, Thoreau's writings enable us to examine how terrorism has changed the ways we write and think about political dissent. Mehanna's visual and verbal exegesis of Thoreau, and his insertion of a Muslim voice into American history, tell us much about the potential for cross-confessional solidarity in post-9/ I I America to reconstruct a broader political agenda. To make these claims for the importance of Mehanna's voice, and the wrongfulness of his imprisonment, is not to defend any ideology that condones violence. Violence is indeed the weak spot in Mehanna's extant work, and he has not offered an adequate statement regarding his views, which may of course have evolved since 20I2. Instead of dwelling on the limits of his thought, I have sought here to demonstrate how this body of work helps us move beyond empty polarities that oppose Islam to the West, and recognize the confluence of beliefs, cultures, and ideologies that informs post-9/I I America, notwithstanding the many violent attempts from the highest echelons of power to undermine our diversity.

\section{AUTHOR BIOGRAPHY}

Rebecca Gould is a Professor of the Islamic World and Comparative Literatures at the University of Birmingham. Her books include Writers and Rebels: The Literatures of Insurgency in the Caucasus (2016), After Tomorrow the Days Disappear: Ghazals and Other Poems of Hasan Sijzi of Delhi (2016), and The Prose of the Mountains: Tales of the Caucasus (2015). I wish to thank Elizabeth Gould for editorial assistance in preparing this article.

59 Brian T. Edwards, "The World, the Text, and the Americanist," American Literary History, $25, \mathrm{I}(2013), 23 \mathrm{I}-46,232$. 